\title{
WIM WENDERS LEITOR DE WALTER BENJAMIN BERLIM: CAPITAL DO SÉCULO XX
}

Rafael Zacca Fernandes é formado em História pela Universidade Federal Fluminense, mestrando em Filosofia, na área de Estética, pelo Programa de Pós-Graduação em Filosofia nessa mesma Universidade.

E-mail: zacca.rafael@gmail.com

\section{Resumo}

O objetivo deste ensaio é apresentar uma crítica do filme Asas do desejo, de Wim Wenders, à luz da filosofia de Walter Benjamin, a partir da compreensão de Berlim como a capital do século $\mathrm{XX}$.

\begin{abstract}
The objective of this essay is to present a critic of Wings of Desire, by Wim Wenders, based on Walter Benjamin's philosophy, comprehending Berlin as the XX Century capital.
\end{abstract}

\begin{abstract}
Assim o apaixonado pela vida universal entra na multidão como se num reservatório de eletricidade. Pode-se igualmente compará-lo a um espelho tão imenso quanto essa multidão; a um caleidoscópio dotado de consciência, que, a cada um de seus movimentos, representa a vida múltipla e o encanto cambiante de todos os elementos da vida.
\end{abstract}

\section{O pintor da vida moderna, Charles Baudelaire}

\section{1) Introdução}

Quando o filósofo Walter Benjamin dedicou-se a estudar a Paris do século XIX ele sabia que Charles Baudelaire se apresentava como uma imagem potente da modernidade. $\mathrm{O}$ poeta encerrava em si tanto a multiplicidade de Paris, a capital do século XIX para o filósofo, como a multiplicidade da era moderna, oculta nas diversas faces de Baudelaire como o poetatrapeiro, o poeta-dândi ou o poeta-herói. Ele aparece, em diferentes imagens apresentadas por Benjamin, como um medium-de-reflexão apropriado para compreender a modernidade.

Pretendo aqui apresentar uma crítica do filme Asas do desejo (1987) de Wim Wenders à luz da filosofia de Walter Benjamin, que, além de influência direta sobre Wenders, como evidenciado em um dos escritos do cineasta no livro The logic of images, levanta e constela temas igualmente presentes no filme. E se, ao desdobrar a poesia de Baudelaire, Benjamin acredita descobrir em Paris a capital do século XIX por concentrar as suas questões mais próprias, proponho que um desdobrar do filme de Wenders é uma tentativa de conceber Berlim como a capital do século XX.

Esta crítica tenta mostrar como o filme de Wenders pode ser lido e vislumbrado como um grande diálogo com a obra de Walter Benjamin (principalmente com seus últimos escritos, da década de 1930). Para tanto, irei oferecer uma leitura do filme por três entradas diferentes: a) a diferença entre anjos e homens no filme e a queda do anjo Damiel como a perda da aura da obra de arte; b) a história de Berlim e a história do século XX como uma 
história que, catastrófica, ainda pode ser redimida; e c) o papel do narrador - ou do artista na condição moderna.

\section{2) Os anjos, os homens e a transcendência ou A vida moderna e a perda da experiência}

Asas do desejo conta a história de Damiel (Bruno Ganz), um dos anjos que habitam Berlim nos anos 1980, e sua vontade de "cair". O anjo, que a tudo espreita graças à sua condição etérea, é seduzido pela possibilidade de uma vida "sensacional" ao preço da mortalidade.

No livro The logic of images há uma série de anotações contendo os primeiros apontamentos para a realização do filme. A vontade que relampejou em Wenders foi fazer um filme em e sobre Berlim. Diz o cineasta que há uma experiência única na cidade que remete ao fato de que o século XX e sua história estariam concentrados em Berlim, que passou por duas guerras mundiais, viu a ascensão do nazismo, e vive (na década de 1980) dividida em duas. "O céu sobre Berlim" (tradução literal do título original do filme, Das Himmel Über Berlin) seria a única coisa que faria sentido na cidade, a única coisa que não seria dividida. A história que Wenders queria contar não era uma história da unidade, mas da divisão. Uma história que se desenrolasse em um mundo cindido em classes, em gêneros, em sistemas econômicos, em sistemas políticos.

Os anjos de Wenders estão fora deste mundo cindido, eles testemunham o mundo da perspectiva de quem pode a tudo assistir. Mas apenas aqueles que estão no mundo dividido (os mortais) é que têm alguma potência. Esta é uma tensão primordial, que se dá no contraste estabelecido pelo jogo de cores do filme, onde o ponto de vista dos anjos, sempre em preto e branco, faz com que a câmera possa visitar lugares ocultos, como as janelas de diversos apartamentos, ou o interior de uma ambulância, descobrindo pensamentos de personagens anônimos, como uma grávida, um casal de velhinhos, ou um moribundo. O preço a ser pago é a ausência de cores. Quando Damiel cai (em frente ao Muro) e descobre as cores (subitamente o filme é colorido), ele passa por um desconhecido e pergunta a ele como elas se chamam. Ele conhece os nomes das cores, sabe que existem o amarelo, o azul e o vermelho, mas é incapaz de dizer qual é qual, porque até então só pôde imaginá-las. Nenhum anjo conhece verdadeiramente as cores.

Se nos detivermos agora sobre o tema da vida em Berlim, poderemos recuperar reflexões de Benjamin sobre a pobreza de experiência (ou Erfahrung) de nossos tempos e esclarecer a história da divisão. O filósofo articula os conceitos de memória e experiência ${ }^{1}$ para iluminar a vida passada e a vida contemporânea à luz da possibilidade ou impossibilidade de se ter uma vida sem cisões. A experiência, característica de uma vida una, teria o seu desenrolar em contextos tradicionais, quando o mundo é orientado pelo seu passado. Os rituais da tradição tinham como função um amortecimento dos estímulos vindos do mundo exterior; eles religavam os estímulos em um dado sentido orientado pelo passado. A modernidade inaugurou a tendência à dissolução destes amortecimentos, e a um aumento do número de estímulos impactantes, que tomam a forma de um choque. O ritual unifica, o 
choque desagrega: quanto mais o indivíduo é submetido a choques, mais sua consciência irá operar, produzindo mais "vivência" (ou Erlebnis - um evento assistido pela consciência) e menos "experiência" (evento acumulado ao longo do tempo de forma inconsciente).

O que o filme de Wenders nos apresenta é a vivência nas grandes metrópoles contemporâneas. Não só quando conhecemos indivíduos submetidos a uma grande quantidade de choques - como fica evidenciado pelo caráter desconexo e um tanto perdido de diversos personagens anônimos que são visitados pelos anjos -, mas também quando nos detemos sobre a estrutura do filme. Diversos elementos heterogêneos entram em cena a favor de diferentes aspectos e temas do filme, constelados fragmentariamente, ainda que sempre em diálogo. É assim que em alguns minutos de filme somos apresentados: aos anjos que povoam Berlim; a Peter Falk, ex-anjo e ator em uma investigação de como será seu personagem em um filme policial inspirado na época do nazismo; a Homero, um narrador velho e cansado que reflete sobre guerra, paz e história; entre outros personagens e locais aparentemente desconexos.

Ademais, o ponto de vista dos anjos realça o caráter de indivíduo isolado, de indivíduo não integrado: os personagens não nos são apresentados segundo seus nomes, suas histórias de vida ou suas relações com outros personagens. A eles somos apresentados a partir das habilidades dos anjos, que alcançam seus pensamentos cotidianos entrecortados por suas angústias - como angústias repousadas não em histórias individuais, mas em uma situação coletiva $^{2}$.

A descoberta de Marion (Solveig Dommartin) é marcante, neste sentido. A trapezista é uma mulher que se declara sem pátria, sem família e sem história. Também ela está desintegrada na "vivência". Ela está sempre cara a cara com o risco, o imprevisível e o nãofamiliar. Uma personagem que tem medo da morte, mas que ainda assim aceita o risco, como escolha. Sob o testemunho de Damiel, o anjo que cairá por esta mulher solitária algum tempo depois, Marion diz:

Uma mulher sozinha, gloriosamente sozinha. Sim, é isso. Tudo tão vazio, incompatível. O vazio, o medo. Como um pequeno animal, perdido nos bosques. Quem é você? Já não sei mais (...) Berlim... Aqui sou uma estranha, e ainda assim tudo é tão familiar. Você pode se perder, que sempre vai parar no Muro.

Marion está sozinha, ainda que cercada pelas multidões da cidade grande. Baudelaire conheceu também a dialética da massificação que opõe e atrai a multidão e a solidão. Diz o poeta: "Multidão, solidão: termos iguais e conversíveis para o poeta diligente e fecundo. Quem não sabe povoar a sua solidão também não sabe estar só em meio a uma multidão atarefada." (Baudelaire, 1995, p. 289)

"Em Baudelaire, a massa é de tal forma intrínseca que em vão buscamos nele a sua descrição." (Benjamin, 1989, p. 115) O poeta e seus contemporâneos conheceram o surgimento das massas na grande cidade. Este é um fenômeno eminentemente moderno. Não é à toa que este é um dos grandes temas da literatura européia do século XIX, como em Edgar Allan Poe (do conto "O homem das multidões") ou em Victor Hugo (vale lembrar que foi o 
primeiro a dar títulos coletivos às suas obras, como Os miseráveis, ou Os trabalhadores do mar, que então eram novidade). Diversos poemas de Baudelaire só podem ser entendidos se levarmos em conta o elemento que é a massa, mesmo que não haja nesses poemas uma descrição destes aglomerados urbanos.

Para Benjamin, no poema "A uma passante" não há uma descrição da massa, mas ele só é possível e visualizável através desse elemento:

Que luz... e a noite após! - Efêmera beldade

Cujos olhos me fazem nascer outra vez,

Não mais hei de te ver senão na eternidade?

(Baudelaire, 1995, p. 179)

A mulher que passa pelo poeta não está sozinha: ela e ele se cruzam na impossibilidade de trocar palavras e possíveis amores, e esta impossibilidade é a massa. Mas a massa não retira do poeta seu objeto de desejo, ao contrário, apenas ela foi capaz de dar-lhe a visão do seu amor que não é apenas à primeira vista, mas também à última vista. O desejo que acomete o solitário só é possível porque ele não mais será capaz de ver a mulher que deseja. A sua imagem é relampejante, e não pode ser fixada.

Desde o século XIX (o modelo de Benjamin é a Paris de Haussmann), as grandes metrópoles do mundo capitalista passam por uma grande quantidade de obras e reformas destinadas a, entre outras funções, intensificar o fluxo de pessoas e mercadorias (além do aparelho repressor do Estado - é preciso lembrar que o século XIX é o século das barricadas). Com essas grandes vias abertas potencializam-se as massas urbanas. Ela desenvolveu-se mais radicalmente no século XIX, segundo Benjamin, em Londres (e aqui leituras de Dickens, Engels ou Poe dão o tom dessas multidões), mas também em Paris ela se tornou parte integrante da urbe. A configuração das grandes cidades e das massas faz com que as pessoas tenham que passar minutos ou horas frente a frente, observando-se, sem se dirigirem uma só palavra, e esta condição não seria acolhedora. As massas escondem qualquer vestígio dos indivíduos, e não é à toa que justo neste contexto nasça o romance policial, com Poe. $\mathrm{O}$ elemento "primitivo", substancial, com o qual trabalha o romance policial é "a supressão dos vestígios do indivíduo na multidão da cidade grande.” (BENJAMIN, 1984, p. 41) A massa oculta o tipo anti-social. Baudelaire foi leitor atento de Poe, e este elemento primordial do romance policial - a supressão dos vestígios do indivíduo na massa - está na obra do poeta, mesmo que ele nunca tenha escrito um romance policial.

Ainda que haja diferenças cruciais entre o poeta e o cineasta - marcadas principalmente pelas épocas a que foram destinados - este procedimento com relação às multidões lhes é familiar. Também Wenders não precisa nos mostrar as massas da metrópole para que elas estejam presentes em seu filme. O indivíduo isolado apresentado, como o suicida com fones de ouvido que se esqueceu de por que irá se jogar, só é possível em um mundo que oculta os homens. Com seus anjos, Wenders permite uma perseguição aos vestígios que separam os homens da massa. Em um prédio de apartamentos aparentemente uniformes descobrimos pequenas histórias, como o homem que está sozinho e lembra da 
amada que o deixou, ou o casal que não sabe o que fazer do filho que só quer tocar rock $n$ ' roll. A câmera solidariza-se com o lado oculto da vida moderna.

A situação do homem isolado remete a uma nostalgia do indivíduo pela totalidade, pelo transcendente. Em The logic of images Wenders diz que esta nostalgia foi também um impulso para a realização do filme. O filme aponta um caminho possível para suprir esse desejo.

\section{3) A queda de Damiel ou A perda da auréola}

Há uma cena em que Damiel e Cassiel (Otto Sander) estão em um conversível em uma loja de carros e conversam sobre coisas que testemunharam no seu dia. Os anjos reuniram fragmentos do dia que são espantosos, por vezes inexplicáveis, como: um preso que bate a cabeça contra a parede e grita: "agora"; um homem velho que lia a Odisseia para uma criança que ouvia sem piscar os olhos; uma mulher que fechou seu guarda chuva em um dia chuvoso e ficou encharcada. Após o relato dos anjos do que apenas testemunharam, Damiel diz:

É fabuloso viver só em espírito, dia a dia, eternamente... testemunhar o que é espiritual nas pessoas. Mas às vezes fico farto com a minha existência espiritual. Gostaria de deixar de flutuar eternamente nas alturas. Gostaria de sentir meu peso acabar com a ausência de fronteiras e me unir à Terra.

Esta é a saga de Damiel: ele quer e irá deixar de ser um anjo. Os anjos sabem o que são as sensações e os sentimentos, podem imaginá-los, mas não senti-los. Os anjos são pura consciência. $\mathrm{O}$ mundo físico e sensual é reservado aos homens, ao preço da morte.

Está formalmente inscrita no filme a insensibilidade dos anjos, que, por um lado, enxergam o mundo sem cores (e é assim que grande parte do filme é filmada em preto e branco), e, por outro, às vezes tentam simular sensações humanas, como Cassiel, que após a queda do suicida tenta se jogar de uma grande altura, sem conseguir, no entanto, provar do gosto da morte.

Peter Falk, engajado defensor da queda dos anjos, tenta Damiel. Assim diz o ex-anjo, em frente a um trailer onde se compram coisas baratas, como café e cigarros:

Não posso vê-lo, mas sei que está aí. Eu posso sentir. (...) Gostaria de poder ver seu rosto, apenas olhar nos seus olhos, e dizer o quanto é bom "ser". Apenas tocar algo. (...) Veja. Fumar, tomar um café. E os dois juntos é fantástico. Ou desenhar. Você pega um lápis e faz um ponto, depois uma linha reta, e juntas formam uma boa linha. Ah, e se suas mãos estiverem frias, você as esfrega. Vê? É muito agradável. Existem tantas coisas boas! Mas você não está aqui. Eu sim.

Damiel não está no mundo, segundo Peter Falk. Damiel apenas o testemunha - e disto o anjo tem plena consciência. Ele não é capaz de mover uma pedra: é impotente. Mas a sua queda está relacionada não só à possibilidade sensorial de Damiel: ela faz parte do 
posicionamento estético de Wenders. A queda do anjo nos diz: é preciso aceitar a perda da aura nas obras de arte. Aqui é preciso retornar a Baudelaire.

Há um poema nos Pequenos poemas em prosa que está também inserido em um debate estético, e que se posiciona do mesmo lado que Asas do desejo. Ele se chama "Perda da auréola", e nos apresenta um diálogo do qual destaco o seguinte trecho:

- Mas o quê? você por aqui, meu caro? Você em tão mal lugar! você, o bebedor de quintessências! você, o comedor de ambrosia! Francamente, é de surpreender.

- Meu caro, você bem conhece meu pavor dos cavalos e das carruagens. Ainda há pouco, quando atravessava a toda a pressa o bulevar, saltitando na lama, através desse caos movediço onde a morte chega a galope por todos os lados a um só tempo, a minha auréola, num movimento precipitado, escorregou-me da cabeça e caiu no lodo do macadame. Não tive coragem de apanhá-la. Julguei menos desagradável perder as minhas insígnias do que ter os ossos rebentados. De resto, disse com meus botões, há males que vêm para bem. Agora posso passear incógnito, praticar ações vis, e entregar-me à crápula, como os simples mortais. E aqui estou, igualzinho a você, como está vendo! (...) Estou bem assim. Só você me reconheceu. Aliás, a dignidade me entedia. Depois, alegra-me pensar que talvez algum mau poeta encontre a auréola e com ela impudentemente se adorne. Fazer alguém feliz, que prazer! e sobretudo um feliz que me fará rir!

(Baudelaire, 1995, p. 333)

Em suas reflexões sobre Baudelaire e no célebre ensaio sobre A obra de arte na era de sua reprodutibilidade técnica, Benjamin caracterizou o que ele chamou de "perda da aura". A obra de arte possuía, desde a antiguidade clássica, uma função ritualística, sendo objeto de culto. Com o estágio da técnica e com a reprodução técnica das obras de arte, a função de culto da obra - a aura que carrega em torno de si - começa a desaparecer ${ }^{3}$. O fundamento teológico da arte perde sua legitimidade, e a obra de arte "se emancipa, pela primeira vez na história, de sua existência parasitária, destacando-se do ritual”. (Benjamin, 1994, p. 171) O ritual é o lar do belo na arte, e se ele aos poucos desaparece, o belo também deve desaparecer das obras. É disto que se trata quando se fala da perda da aura. A aura e a tradição tendem à desintegração em condições de modernidade. A obra de arte não faz mais justiça aos deuses e aos imortais - o homem do poema em prosa perde sua auréola para sentir-se como um mortal. Benjamin diz que este é o preço a pagar para que um homem sinta a modernidade: a desintegração da aura na vivência do choque.

A modernidade trouxe uma grande quantidade de inovações, ocorridas em meados do século XIX, que têm em comum a disparada de uma série de processos complexos com um simples gesto. Experiências ópticas e táteis novas submeteram o indivíduo a uma quantidade grande de choques. São experiências essencialmente estimulantes.

Com a invenção do fósforo, em meados do século passado, surge uma série de inovações que têm uma coisa em comum: disparar uma série de processos complexos com um simples gesto. A evolução se produz em muitos setores; fica evidente entre outras coisas, no telefone, onde o movimento habitual da manivela do antigo aparelho cede lugar à retirada do fone do gancho. Entre inúmeros gestos de comutar, inserir, acionar etc., especialmente o 'click' do fotógrafo trouxe consigo muitas conseqüências. Uma pressão do dedo bastava para fixar um acontecimento por tempo ilimitado. $\mathrm{O}$ aparelho como que aplicava ao instante um choque 
póstumo. Paralelamente às experiências ópticas desta espécie, surgiram outras táteis, como as ocasionadas pela folha de anúncio dos jornais, e mesmo pela circulação na cidade grande. $\mathrm{O}$ mover-se através do tráfego implicava uma série de choques e colisões para cada indivíduo. Nos cruzamentos perigosos, inervações fazem-no estremecer em rápidas sequências, como descargas de uma bateria. (BENJAMIN, 1989, p. 124)

O choque é a nova condição do homem moderno, quando uma série de eventos dispersos e aleatórios ocorre simultaneamente. Os poemas de Baudelaire são feitos segundo um princípio de dispersão: ele não visa a um leitor atento e contemplativo, afeito às regras do Belo; ele quer um leitor disperso, capaz de assimilar uma grande quantidade de choques simultâneos. Sua obra tanto mais ganhou o mundo quanto mais o mundo modernizou-se.

A obra de arte então se apresenta como lugar privilegiado para se entender as modificações na percepção dos homens. Se a natureza da obra de arte se modificou, e novas formas surgiram (como a fotografia ou o cinema), isto se deve, para Benjamin, a uma exigência histórica da própria modernidade. Segundo o filósofo, o estágio da técnica trazia consigo a promessa de libertar-nos da natureza,

\begin{abstract}
mas essa técnica emancipada se confronta com a sociedade moderna sob a forma de uma segunda natureza, não menos elementar que a da sociedade primitiva, como provam as guerras e as crises econômicas. Diante dessa segunda natureza, que o homem inventou mas há muito não controla, somos obrigados a aprender, como outrora diante da primeira. Mais uma vez, a arte põe-se a serviço desse aprendizado. Isso se aplica, em primeira instância, ao cinema. O filme serve para exercitar o homem nas novas percepções e reações exigidas por um aparelho técnico cujo papel cresce cada vez mais em sua vida cotidiana. Fazer do gigantesco aparelho técnico do nosso tempo o objeto das inervações humanas - é essa a tarefa histórica cuja realização dá ao cinema o seu verdadeiro sentido. (BENJAMIN, 1994, p. 174)
\end{abstract}

O anjo, como o poeta do poema de Baudelaire, perde a sua auréola, com o objetivo de assombrar-se, seja com o amor, com Marion, seja com as cores ou com o gosto de seu próprio sangue. Para completar sua queda Damiel precisa não apenas se desfazer de sua proteção - a sua armadura de anjo - como também vendê-la numa loja de antiguidades. Por seu turno, a obra de arte assume seu caráter fragmentário e não tenta recriar uma atmosfera mística de Beleza, perdendo sua aura, assumindo as descontinuidades entre as cenas. Asas do desejo advoga a causa dos ex-anjos, a quem o filme é dedicado - especialmente a três deles, segundo uma inscrição de Benjamin na última cena do filme: Yasujiro Ozu, François Truffaut e Andrei Tarkovski, três cineastas admirados pelo diretor. Não há fantasmagoria, apesar da história sobre anjos: Damiel e Cassiel são presenças físicas no filme. Os outros atores encenam como se eles não estivessem ali. Já os espectadores vêem-nos não semitransparentes, mas fisicamente. Uma das poucas imagens vacilantes está no início do filme, as asas de Damiel em suas costas, que denunciam que aquele é um anjo.A nostalgia pela transcendência - ou pela aura da obra de arte - pode ser respondida de algumas formas: uma delas foi a tentativa nazista de estetização da vida política e social; Benjamin diz que o comunismo deveria responder com a politização das obras de arte; Wenders mostra que não é 
nos anjos que se deve mirar, mas na vida que temos, com suas sensações absurdas e cores assombrosas.

\section{4) Uma epopeia da paz ou A posição do narrador na modernidade}

Quando o anjo Damiel decide cair - após estar convencido de seu desejo por Marion e pelas promessas de uma vida sensacional, defendida também pelo ex-anjo Peter Falk - a primeira coisa que faz é lamber o próprio sangue e perguntar a um estranho os nomes das cores. Depois toma um café puro para esquentar o corpo. Então anda pelas ruas de Berlim, descobrindo como é ser no mundo, espantado. O poema de Peter Handke, que é recitado diversas vezes no filme, pode ser ouvido durante esta caminhada, gerando certo estranhamento e conciliando cena e palavra. Das outras vezes que trechos do poema apareceram no filme, eles diziam: "Quando a criança era criança" alguma coisa a espantava ${ }^{4}$. O espanto como nostalgia. Desta vez, porém, o poema fala de alguma coisa que persiste, como a esperança de que a infância não esteja totalmente perdida.

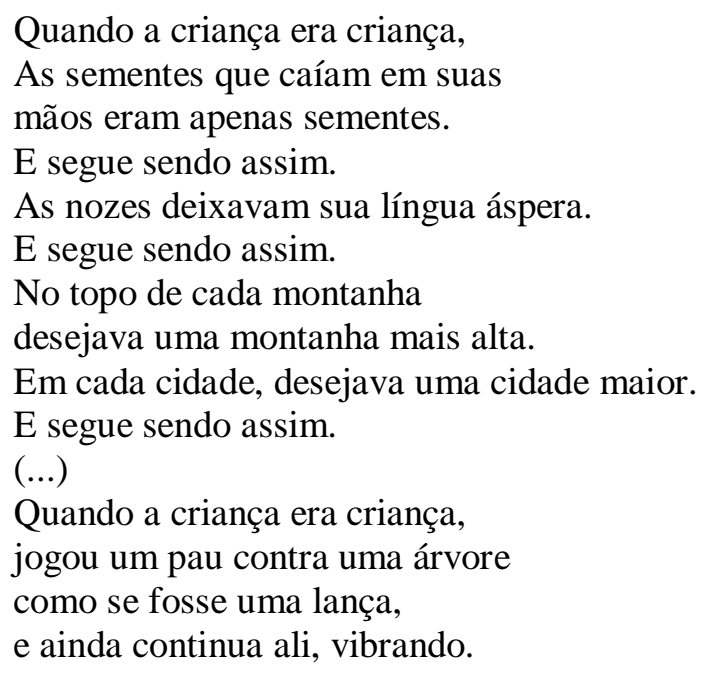

A queda de Damiel é a sua possibilidade de experimentar as coisas como a criança as experimenta. Isto está diretamente conectado com o diálogo que o filme estabelece com a história das guerras que assolam a humanidade e mesmo com o amor entre Marion e Damiel. Quando o ex-anjo está prestes a beijar a trapezista, ela decide dizer algumas coisas antes que o amor se concretize:

Devo finalmente procurar algo sério. Já estive sozinha por muito tempo, mas nunca vivi sozinha. Quando estava com alguém, quase sempre era feliz. Mas, ao mesmo tempo, me parecia só coincidência. Aquelas pessoas eram meus pais, mas podiam ter sido outras pessoas. Por que meu irmão era o garoto de olhos castanhos, e não o garoto de olhos verdes do outro lado da rua? A filha do taxista era uma amiga minha, mas em vez do táxi, poderia ter andado à cavalo. Estava apaixonada por um homem, mas poderia tê-lo deixado para ir com o primeiro estranho que se cruzasse conosco na rua. Me olhe, ou não me olhe. Dê-me a mão, ou não me dê. Não. Não me dê a mão. E olhe para o outro lado. Acho que hoje é lua nova. A noite não 
poderia ser mais calma. Por toda a cidade não correrá sangue. Nunca brinquei com ninguém. Mas também nunca abri os olhos e pensei: agora é sério. Até que enfim é sério. Então comecei a envelhecer. Era a única que não tinha algo sério? Será a época em que vivemos pouco séria? Nunca estive sozinha. Nem com os demais, nem comigo mesma. Mas teria gostado de estar sozinha. A solidão significa ser, por inteiro, um só. Agora posso dizer: finalmente estou só esta noite. Devo colocar um fim na coincidência. A lua nova da decisão! Não sei se existe o destino, mas sei que existem decisões. Decida. Agora somos o tempo. Não só toda a cidade, mas o mundo inteiro participa de nossa decisão. Agora somos mais do que apenas "nós". Encarnamos algo. Estamos sentados na praça do povo, e a praça está repleta de pessoas, que desejam a mesma coisa que nós. Nós decidimos o jogo de todos. Estou pronta. Agora... é a sua vez. Tens as cartas na mão. Agora ou nunca. Me necessitas. Você precisa de mim. Você irá precisar de mim. Não existe nenhuma história mais importante do que a nossa. A do homem e da mulher. Será uma história de gigantes. Invisível, traduzível. A história de novos ancestrais. Olhe. Meus olhos. São a imagem da necessidade, do futuro de todos que estão nesta praça. A noite passada sonhei com um estranho, com meu homem. Só com ele podia estar sozinha. Abrir-me com ele. Abrir-me totalmente. Para ele totalmente. Recebê-lo totalmente em mim como algo completo. Cercá-lo no labirinto da felicidade compartilhada. Sei que é você.

A fala de Marion não deixa dúvidas de que o amor entre ela e Damiel se trata de uma missão, e é algo que os ultrapassa. O encontro do anjo caído com a trapezista sem pátria é a possibilidade de redenção que todo o mundo aguarda. Não nos deve parecer estranho compreender o amor dos dois em relação direta com o personagem Homero: o que os interliga é a história de Berlim e do mundo.

Os anjos vêem diversas histórias: são capazes de ver a Berlim nazista durante a Segunda Grande Guerra, a Berlim pós-guerra em ruínas, a Berlim pós-guerra dividida, eventos que se passaram há duzentos anos, e mesmo o início dos tempos. Porque os anjos não conhecem o tempo, estão fora dele, apenas sabem que ele existe, mas não são capazes de senti-lo, pois não possuem a finitude. É curioso como diversas potências dos anjos vêm também daquilo que eles não têm. Berlim, no que se refere principalmente à história europeia, foi palco das duas guerras mundiais, conhecendo o horror do Terceiro Reich, e, quando o mundo foi dividido em dois blocos (o capitalista e o soviético), a cidade mesma se viu dividida ao meio, por um imenso muro que consolidava a história da divisão. O século XX está, sob estes aspectos, condensado fisicamente nas ruínas da cidade.

Quanto a Homero, trata-se de um narrador velho e cansado, acompanhado por Cassiel nas suas longas caminhadas por Berlim. Homero aqui encarna diversos papéis: ele é um homem que teve a sua experiência destruída, é também a imagem do narrador na contemporaneidade (em outras palavras, ele é uma possibilidade de artista frente a um mundo que conhece como história dominante a história da guerra) e é, finalmente, alguém semelhante a um ex-anjo, que sabe que por trás das ruínas está a história de Berlim e todas as histórias que a cidade poderia ter vivido e que foram recalcadas frente à história da guerra (quando Homero caminha por Berlim, ele vê não somente o que a cidade apresenta aos seus olhos, mas também as imagens dos tempos de guerra - são imagens documentais do terror do século XX). 
Quando aparece pela primeira vez, Homero dialoga diretamente com um ensaio de Walter Benjamin, intitulado $O$ narrador. Homero diz:

Musa, fale-me sobre o narrador. Nos confins do mundo, para a criança e o ancião, revele todos através dele. Com o tempo, meus ouvintes tornaram-se meus leitores. Não se sentam mais em círculo, mas sozinhos. E um desconhece o outro. Sou um velho de voz fraca, mas o conto continua brotando do meu interior. A boca, ligeiramente aberta, repete-o com força e clareza. Liturgia que não exige iniciação para que se entenda o sentido das palavras e frases.

No referido ensaio, Benjamin analisa as modificações do lugar do narrador quando o mundo modifica suas feições tradicionais para modernas. $\mathrm{O}$ narrador recorre, para narrar, à experiência transmitida de pessoa a pessoa. O narrador dá conselhos. Com a perda da experiência, narrar se torna mais difícil. A sabedoria, "o lado épico da verdade", está se extinguindo com a arte de narrar.

O saber que vinha de longe (no tempo ou no espaço) tinha uma autoridade, este diz respeito à narração, que traz o seu saber da tradição ou de outras terras visitadas. A informação sobre os acontecimentos próximos possui, hoje, mais ouvintes interessados. A informação precisa ser compreensível em si e para si. A informação é também responsável pelo declínio da narrativa. Para Benjamin, nos tornamos pobres em histórias surpreendentes, pois as informações já vêm acompanhadas de explicação. Evitar explicações é próprio da narrativa, o que lhe dá uma amplitude ausente na informação. A força da narração, ao contrário da informação, está em que ela é aberta a diversos desfechos, ela não possui em si nenhuma explicação.

O processo de assimilação exige um estado de distensão do ouvinte, estado que vem se tornando mais raro. O tédio é o ponto mais alto da distensão psíquica. O tédio está sumindo, e com ele os ouvintes dos narradores. Com o desaparecimento do dom de ouvir, desaparece toda uma comunidade de ouvintes, que se desenvolveu, conjuntamente com os narradores, associada ao trabalho manual. A narrativa é uma forma artesanal de comunicação. A coisa comunicada não se transmite pura, ela é banhada da experiência do narrador. Há vestígios do narrador na coisa narrada. $\mathrm{O}$ mundo moderno desagregou as condições históricas propícias para esta narração primordial, e por isso as manifestações estéticas precisam modificar-se.

A pergunta que Homero dirige às musas pelas suas falas é: como narrar em um mundo desagregado, destradicionalizado e em ruínas? Pois, segundo ele, se a humanidade perder o seu narrador, "perderá também o seu lado criança".

Neste momento o filme de Wenders dá a sua leitura da filosofia de Benjamin: este é um mundo de indivíduos isolados, que está perdendo a sua experiência. Esta experiência é associada tanto à criança, pelo poema de Peter Handke que entrecorta diversas cenas, como à possibilidade do espanto. Trata-se, portanto, de se perguntar o lugar do narrador no mundo contemporâneo e como ele pode resgatar a experiência que se perde, ou ainda a infância que se perde. Esta é uma posição que dialoga na direção oposta ao que diz Benjamin, que ostenta a pobreza de experiência. 
No ensaio Experiência e pobreza, Benjamin apresenta aquilo que seria a pobreza de experiência. Esta pobreza faria parte de uma pobreza maior, à qual estamos todos submetidos. Frente a esta situação, é preferível assumirmos essa pobreza, que é de toda a humanidade. Ela pode ser caracterizada como uma nova barbárie. Mas a "nova barbárie" aparece como um conceito novo e positivo. O bárbaro é aquele que se contenta com a pobreza de experiência, aquele que assume que tem pouco, e que com este pouco cria o que precisa. Há em "algumas das melhores cabeças" uma desilusão com o século, e ao mesmo tempo uma fidelidade a ele. Para Benjamin, é preciso rejeitar a nostalgia de um passado melhor.

Tanto um pintor complexo como Paul Klee quanto um arquiteto programático como Loos rejeitam a imagem do homem tradicional, solene, nobre, adornado com todas as oferendas do passado, para dirigir-se ao contemporâneo nu, deitado como um recém-nascido nas fraldas sujas de nossa época. (BENJAMIN, 1994, p. 116)

Asas do desejo não quer recriar a tradição, mas se pergunta sobre como resgatar a experiência. A resposta de Wenders aponta para a infância e para o espanto. Mas esta redenção da humanidade está associada também a uma história que não foi e poderia ter sido. É uma história que pode ser recuperada. Ela pode ser redimida com o amor de Damiel e Marion. Homero, em meio às ruínas da praça Potzdammer, diz:

O mundo some no crepúsculo. Mas continuo narrando como no início. Na minha voz cantante que me sustenta. Este relato me exime dos distúrbios do presente e me protege do futuro. Chega de pensar nos séculos passados e futuros. Eu agora só penso num dia de cada vez. Minha admiração não mais pertence aos guerreiros e reis, mas sim aos objetos de paz, todos igualmente válidos. A cebola seca é tão válida quanto a carcaça de árvore que atravessa o pântano. Mas ninguém conseguiu ainda cantar um épico sobre a paz. O que há de errado com a paz que sua inspiração não dura... tempo suficiente para ter a estória contada?

Os anjos são capazes de ver as gerações anteriores, são capazes de ver as histórias que poderiam ter sido. Homero é uma história nova que poderá ser, assim como Marion e Damiel. Marion fala da história de novos ancestrais. Homero não possui mais admiração pelos guerreiros e reis, que fizeram a história da guerra, mas por objetos de uma história que não vingou, a da paz. Cassiel e Damiel lembram em sua conversa que a história dos espantos não findou. Tudo isto aponta para o fato de que

Quando a criança era criança, jogou um pau contra uma árvore como se fosse uma lança, e ainda continua ali, vibrando.

Wenders disse no referido livro de escritos reunidos que uma de suas influências para conceber o filme foi o anjo da história de Benjamin. O anjo da história está em uma de suas teses Sobre o conceito de história. Assim diz a nona tese, que inspirou Wenders: 
Há um quadro de Klee que se chama Angelus Novus. Representa um anjo que parece querer afastar-se de algo que ele encara fixamente. Seus olhos estão escancarados, sua boca dilatada, suas asas abertas. O anjo da história deve ter esse aspecto. Seu rosto está dirigido para o passado. Onde nós vemos uma cadeia de acontecimentos, ele vê uma catástrofe única, que acumula incansavelmente ruína sobre ruína e as dispersa a nossos pés. Ele gostaria de deter-se para acordar os mortos e juntar os fragmentos. Mas uma tempestade sopra do paraíso e prende-se em suas asas com tanta força que ele não pode mais fechá-las. Essa tempestade o impele irresistivelmente para o futuro, ao qual ele vira as costas, enquanto o amontoado de ruínas cresce até o céu. Essa tempestade é o que chamamos progresso. (Benjamin, 1994, p. 226)

Esta é a história das ruínas e da guerra. Mesmo o nazismo não aparece, no filósofo, em 1940, como um estado de exceção: ele seria a regra. Na oitava tese diz: "a tradição dos oprimidos nos ensina que o 'estado de exceção' em que vivemos é na verdade a regra geral." (Benjamin, 1994, p. 226) A salvação não está na crença de um futuro melhor, pois o futuro em uma história da guerra é o acúmulo de ruínas. A salvação está em outras histórias que foram reprimidas. Diz a segunda tese que

O passado traz consigo um índice misterioso, que o impele à redenção. Pois não somos tocados por um sopro do ar que foi respirado antes? Não existem, nas vozes que escutamos, ecos de vozes que emudeceram? Não têm as mulheres que cortejamos irmãs que elas não chegaram a conhecer? Se assim é, existe um encontro secreto, marcado entre as gerações precedentes e a nossa. Alguém na terra está à nossa espera. Nesse caso, como a cada geração, foi-nos concedida uma frágil força messiânica para a qual o passado dirige um apelo. Esse apelo não pode ser rejeitado impunemente. O materialista histórico sabe disso. (Benjamin, 1994, p. 223)

Marion encarna este apelo, no momento em que ela não só diz a referida fala, mas o faz de frente para a câmera, e nos faz vacilar se ela pede para que Damiel ou nós mesmos, espectadores, tomemos uma decisão. Quando ela diz "decida" ela já não diz apenas ao exanjo, mas a todo o mundo, para que decida entre a história da guerra, e a história do assombro, da infância e da paz.

\footnotetext{
${ }^{1}$ É preciso lembrar que Walter Benjamin se apoia, principalmente, nas reflexões de Marcel Proust e de Sigmund Freud para desenvolver este tema. Cf. o ensaio Sobre alguns temas em Baudelaire.

2 Em um mundo desintegrado, a única "experiência" (ou seja, o único evento coletivo, a marca que une os homens de uma mesma época) é a experiência da "vivência". Todos os homens estão isolados.

${ }^{3}$ Benjamin define, neste ensaio, a aura da seguinte maneira: "É uma figura singular, composta de elementos espaciais e temporais: a aparição única de uma coisa distante, por mais perto que ela esteja. Observar, em repouso, numa tarde de verão, uma cadeia de montanhas no horizonte, ou um galho, que projeta sua sombra sobre nós, significa respirar a aura dessas montanhas, desse galho." (Benjamin, 1994, p. 170) A aura é uma figura singular posto que única, autêntica: é aquilo que a tradição lega ao objeto em questão em matéria de autoridade. Por isso também ela é composta de elementos espaciais e temporais, e não pode ser adquirida por um simples instrumento técnico, nem pode ser abalada apenas por ele. Se a aura é a aparição única de uma coisa distante, por mais perto que ela esteja, e se, ainda, respirar a aura de um galho e de uma montanha significa observar, em repouso, numa tarde de verão estes objetos, é fácil compreender a demanda moderna
} 
pela dissolução da aparição aurática. As massas modernas, segundo o filósofo, possuem o desejo de tornar todas as coisas próximas, e isto é feito mediante uma reprodução potencialmente infinita de todos os objetos que compõem o seu universo; além disso, estas massas possuem um aparelho sensorial mais dispersivo que contemplativo, elas não permitem que o tempo participe, laborioso, do momento da percepção. Pois as massas modernas possuem uma sensibilidade aguda de "captar o semelhante no mundo".

${ }^{4} \mathrm{O}$ filme inicia com os seguintes versos: "Quando a criança era criança, andava / com os braços balançando. / Queria que o córrego fosse um rio, / o rio uma torrente... / e que esta poça fosse o mar. / Quando a criança era criança, não / sabia que era uma criança. / Tudo era cheio de vida, / e a vida era única. / Quando a criança era criança, / não tinha opinião sobre nada. / Não tinha hábitos. / Sempre sentava com as pernas cruzadas, / Saía correndo / os cabelos eram desarrumados, / e não fazia pose quando fotografada."

\section{Referências bibliográficas:}

BAUDElAIRE, Charles. Poesia e Prosa: Volume Único. Rio de Janeiro: Nova Aguilar, 1995.

BENJAMIN, Walter. Obras Escolhidas I. Magia e técnica, arte e política: ensaios sobre literatura e história da cultura. Trad. Sergio Paulo Rouanet. São Paulo: Brasiliense, 1994. Obras Escolhidas III. Baudelaire, um lírico no auge do capitalismo. Trad. José Martins Barbosa, Hemerson Alves Baptista. 1 ${ }^{a}$ Ed. São Paulo: Brasiliense, 1989. WENDERS, Wim; HOFFMAN, Michael. The logic of images: essays and conversations. London: Faber and Faber, 1992.

\section{Referência filmográfica:}

WENDERS, Wim. Asas do desejo. Alemanha, 1987. 128 Min., sonoro/legendado, cor e p\&b. 